\title{
Correction to: Orthotopic model of lung cancer: isolation of bone micro-metastases after tumor escape from Osimertinib treatment
}

Ulrich Jarry ${ }^{1,2^{*}}$, Mégane Bostoën ${ }^{1}$, Raphaël Pineau ${ }^{3}$, Laura Chaillot ${ }^{3}$, Valentine Mennessier ${ }^{2}$, Pierre Montagne ${ }^{2}$, Emilie Motte $^{2}$, Marjorie Gournay ${ }^{3}$, Arnaud Le Goff $^{2}$, Thierry Guillaudeux ${ }^{1,3+}$ and Rémy Pedeux ${ }^{3^{*}+}$

Correction to: BMC Cancer 21, 530 (2021)

https://doi.org/10.1186/s12885-021-08205-9

Following publication of the original article [1], the authors reported that the corresponding authors were incorrectly allocated:

The corresponding authors are Rémy Pedeux (remy. pedeux@univ-rennes1.fr) and Ulrich Jarry (ulrich. jarry@univ-rennes1.fr)

The original article [1] has been corrected.

\begin{abstract}
Author details
${ }^{1}$ Université Rennes 1, UMS 3480 CNRS/US018 INSERM BIOSIT, Laboratoire Commun ONCOTRIAL, Rennes, France. ${ }^{2}$ Biotrial Pharmacology, Unité De Pharmacologie Préclinique, Rennes, France. ${ }^{3}$ INSERM U1242 COSS, Université Rennes 1, Clcc Eugène Marquis, Rennes, France.
\end{abstract}

Published online: 19 May 2021

\section{Reference}

1. Jarry $U$, Bostoën $M$, Pineau $R$, Chaillot $L$, Mennessier $V$, Montagne $P$, et al. Orthotopic model of lung cancer: isolation of bone micro-metastases after tumor escape from Osimertinib treatment. BMC Cancer. 2021;21:530 https:// doi.org/10.1186/s12885-021-08205-9.

\footnotetext{
The original article can be found online at https://doi.org/10.1186/s12885021-08205-9.

*Correspondence: ulrich.jarry@univ-rennes1.fr; remy.pedeux@univ-rennes1.fr

†Thierry Guillaudeux and Rémy Pedeux share senior authorship

'Université Rennes 1, UMS 3480 CNRS/US018 INSERM BIOSIT, Laboratoire Commun ONCOTRIAL, Rennes, France

${ }^{3}$ INSERM U1242 COSS, Université Rennes 1, Clcc Eugène Marquis, Rennes, France

Full list of author information is available at the end of the article
}

(c) The Author(s). 2021 Open Access This article is licensed under a Creative Commons Attribution 4.0 International License, which permits use, sharing, adaptation, distribution and reproduction in any medium or format, as long as you give appropriate credit to the original author(s) and the source, provide a link to the Creative Commons licence, and indicate if changes were made. The images or other third party material in this article are included in the article's Creative Commons licence, unless indicated otherwise in a credit line to the material. If material is not included in the article's Creative Commons licence and your intended use is not permitted by statutory regulation or exceeds the permitted use, you will need to obtain permission directly from the copyright holder. To view a copy of this licence, visit http://creativecommons.org/licenses/by/4.0/. The Creative Commons Public Domain Dedication waiver (http://creativecommons.org/publicdomain/zero/1.0/) applies to the data made available in this article, unless otherwise stated in a credit line to the data. 